\title{
GABA Type B Receptor Signaling in Proopiomelanocortin Neurons Protects Against Obesity, Insulin Resistance, and Hypothalamic Inflammation in Male Mice on a High-Fat Diet
}

\author{
Yoshihiro Ito, ${ }^{1 \star}$ Ryoichi Banno, ${ }^{1 *}$ Miyuki Shibata, ${ }^{1}$ Koichi Adachi, ${ }^{1}$ Shigeru Hagimoto, ${ }^{1}$ Daisuke Hagiwara, ${ }^{1}$ \\ Yoshiharu Ozawa, ${ }^{1}$ Motomitsu Goto, ${ }^{1}$ Hidetaka Suga, ${ }^{1}$ Yoshihisa Sugimura, ${ }^{1}$ Bernhard Bettler, ${ }^{2}$ Yutaka Oiso, ${ }^{1}$ \\ and Hiroshi Arima ${ }^{1}$ \\ ${ }^{1}$ Department of Endocrinology and Diabetes, Nagoya University Graduate School of Medicine, Showa-ku, Nagoya 466-8550, Japan, and ${ }^{2}$ Department of \\ Biomedicine, University of Basel, Basel CH-4056, Switzerland
}

There is evidence suggesting that the GABA system in the arcuate nucleus, where orexigenic neuropeptide Y and agouti-related peptide as well as anorexigenic proopiomelanocortin (POMC) are expressed, plays an important role in energy balance. In this study, we generated POMC-specific $\mathrm{GABA}_{\mathrm{B}}$ receptor-deficient [knock-out (KO)] mice. Male KO mice on a high-fat diet (HFD) showed mild increases in body weight (BW) at the age of 9 weeks compared to wild-type (WT) mice, and the differences remained significant until 16 weeks old. However, there was no difference in BW in females between genotypes. While food intake was similar between genotypes, oxygen consumption was significantly decreased in the male KO mice. The insulin tolerance test revealed that the male KO mice were less insulin sensitive compared to WT mice at the age of 8 weeks, when there was no significant difference in BW between genotypes. Despite increased BW, POMC mRNA expression in the arcuate nucleus was significantly decreased in the KO mice compared to WT mice at the age of 16 weeks. Furthermore, the expression of TNF $\alpha$ as well as IL-6, proinflammatory markers in the hypothalamus, was significantly increased in the KO mice on a HFD compared to WT mice. This demonstrates that the deletion of GABA $\mathrm{B}_{\mathrm{B}}$ receptors in POMC neurons in the male mice on a HFD results in obesity, insulin resistance, and hypothalamic inflammation. Furthermore, the decreased POMC expression in the obese $\mathrm{KO}$ mice suggests that the regulation of $\mathrm{POMC}$ expression through $\mathrm{GABA}_{\mathrm{B}}$ receptors is essential for proper energy balance.

\section{Introduction}

The anorexigenic proopiomelanocortin (POMC) is expressed in the hypothalamic arcuate nucleus. The POMC neurons as well as those expressing orexigenic neuropeptide Y (NPY) and agoutirelated peptide (AgRP) integrate peripheral signals related to energy balance such as leptin, and send these signals to other hypothalamic neurons (Morton et al., 2006). POMC manifests its effects on energy balance via $\alpha$-melanocyte-stimulating hormone $(\alpha-\mathrm{MSH})$ and $\beta-\mathrm{MSH}$, which are cleaved from POMC precursors and bind to melanocortin type 3 and 4 receptors (Harrold et al., 2003; Coll et al., 2004). A pivotal role for POMC neurons in energy homeostasis is supported by several studies; central injection of $\alpha$-MSH or $\beta$-MSH decreases food intake (Fan et al., 1997;

\footnotetext{
Received Feb. 26, 2013; revised Aug. 23, 2013; accepted Sept. 22, 2013.

Author contributions: R.B., B.B., Y. Oiso, and H.A. designed research; Y.I., R.B., M.S., K.A., S.H., D.H., Y. Ozawa, M.G., H.S., and Y.S. performed research; Y.I., R.B., D.H., B.B., and H.A. wrote the paper.

This work was supported in part by a Grant-in Aid for Scientific Research (C) from the Japanese Society for Promotion of Science (20591093), and Swiss National Science Foundation Grant 3100A0-117816. We thank Michiko Yamada and Mayumi Katagiri for their helpful technical assistance.

*Y.I. and R.B. contributed equally to this work.

The authors declare no competing financial interests.

Correspondence should be addressed to Dr. Hiroshi Arima or Ryoichi Banno at the above address. E-mail: arima105@med.nagoya-u.ac.jp or ryouichi@med.nagoya-u.ac.jp.

DOI:10.1523/JNEUROSCI.0897-13.2013

Copyright $\odot 2013$ the authors $\quad 0270-6474 / 13 / 3317166-08 \$ 15.00 / 0$
}

Jonsson et al., 2001; Honda et al., 2012), whereas the injection of a melanocortin receptor antagonist increases food intake in rodents (Fan et al., 1997; Aizawa-Abe et al., 2000; Obici et al., 2001; Nogueiras et al., 2007); whole-body knock-out (KO) mice for POMC (Yaswen et al., 1999) as well as those for melanocortin type 4 receptors showed obesity (Huszar et al., 1997). Previous studies also revealed that POMC neuron-specific deletion of leptin receptors (Balthasar et al., 2004) or molecules related to leptin signaling (Kievit et al., 2006; Xu et al., 2007; Banno et al., 2010) leads to obesity in mice.

GABA, the predominant inhibitory neurotransmitter in the CNS, acts on two types of receptors: ionotropic $\mathrm{GABA}_{\mathrm{A}}$ receptors $\left(\mathrm{GABA}_{\mathrm{A}} \mathrm{Rs}\right)$, which are mainly located postsynaptically, and metabotropic $\mathrm{GABA}_{\mathrm{B}}$ receptors $\left(\mathrm{GABA}_{\mathrm{B}} \mathrm{Rs}\right)$, which are located presynaptically as well as postsynaptically (Enna and McCarson, 2006; Gassmann and Bettler, 2012). It has been demonstrated that (1) the AgRP neurons (Cowley et al., 2001) and POMC neurons (Dicken et al., 2012) are GABAergic, (2) leptin increases the frequency of action potentials in the POMC neurons by reducing GABA release from the AgRP neurons (Cowley et al., 2001), and (3) mice that lack GABA release from the AgRP neurons are lean (Tong et al., 2008). These data suggest that the GABA system in the arcuate nucleus plays an important role in energy homeostasis, although the relative contribution of $\mathrm{GABA}_{\mathrm{B}} \mathrm{Rs}$ compared to 
$\mathrm{GABA}_{\mathrm{A}} \mathrm{Rs}$ in the arcuate nucleus in the energy homeostasis has not been studied yet.

In the present study, we generated mice that specifically lack functional $\mathrm{GABA}_{\mathrm{B}} \mathrm{Rs}$ in POMC neurons. We analyzed their phenotypes with respect to energy balance and glucose tolerance to delineate the role of $\mathrm{GABA}_{\mathrm{B}} \mathrm{R}$ signaling in the POMC neurons.

\section{Materials and Methods}

Mice. All animal procedures were approved by the Animal Care and Use Committee of Nagoya University Graduate School of Medicine and performed in accordance with the institutional guidelines, which conform with the National Institutes of Health animal care guidelines. Mice were maintained on a $12 \mathrm{~h}$ light/dark cycle in a temperature-controlled barrier facility, with free access to water and food. Age-matched littermates were used for all experiments.

Mice with POMC-specific deletion of $G A B A_{B 1}$. $G A B A_{B 1} R^{\text {lox511/lox511 }}$ mice were generated previously (Haller et al., 2004). GABA ${ }_{B}$ Rs consist of principal $\mathrm{GABA}_{\mathrm{B} 1}$ and $\mathrm{GABA}_{\mathrm{B} 2}$ subunits that associate with auxiliary KCTD (potassium channel tetramerization domain-containing) subunits (Gassmann and Bettler, 2012). Principal subunits are essential for function while auxiliary subunits modulate the receptor response, and genetic deletion of the $\mathrm{GABA}_{\mathrm{B} 1}$ subunit leads to complete lack of functional $\mathrm{GABA}_{\mathrm{B}}$ Rs (Schuler et al., 2001; Gassmann and Bettler, 2012). $P O M C$-Cre transgene mice that express functional Cre-recombinase only in POMC cells (Balthasar et al., 2004; hereafter termed POMC-Cre mice) and mice that express enhanced green fluorescent protein (EGFP) upon Cre-mediated excision in cells harboring the deletion event (Novak et al., 2000; hereafter termed $Z / E G$ reporter mice) were purchased from the Jackson Laboratory. Primer sequences used for genotyping of $G A B A_{B 1} R^{\text {lox511/lox511 }}$ and POMC-Cre mice were as follows: $G A B A_{B 1} R$ forward, 5'-TGGGGT GTGTCCTACATGCAGCGGACGG; reverse, 5'-GCTCTTCACCTTTCAACCCAGCCTCAGGCAGGC; POMC-Cre forward, 5' -TGGCTCAATGTCCTTCCTGG; reverse, 5' -CACATAAGCT GCATCGTTAAG [to detect wild-type (WT) gene] or 5'-GAGATATCTTTAACCCTGATC (to detect transgene). Z/EG reporter mice were genotyped using the following GFP primers: forward, 5' -TCATGGCCGACAAGCAGA AGAACG; reverse, 5'-CGGCGGCGGTCACGAACT. DNA was extracted from a drop of blood from each experimental mouse at the age of 8 weeks to check for the occurrence of spurious germline deletion using the following primers: $G A B A_{B 1} R \Delta / \Delta$ forward, 5' ${ }^{\prime}$ ATCTCTTCCTTGGCT GGGTCTTTGCTTCGCTCG; reverse, 5' -GGGTTATTGAATATGATCGGAATTCCTCGACT; GAPDH (for an internal control) forward, 5'-AACGAC CCCTTCATTGAC; reverse, 5'-TCCACGACATACTCAGCAC. All $G A B A_{B 1} R^{l o x 511 / l o x 511}$ mice and POMC-Cre mice were backcrossed $>10$ generations onto a C57BL/6 background.

Isolating DNA from tissues for detection of recombination of floxed alleles. Tissues (pituitary, hypothalamus, hindbrain, cerebral cortex, liver, skeletal muscle, and fat) of mice at the age of 8 weeks were digested by 50 $\mathrm{mm} \mathrm{NaOH}$ for $10 \mathrm{~min}$ at $95^{\circ} \mathrm{C}$, and $1 \mathrm{M}$ Tris- $\mathrm{HCl}(\mathrm{pH} 8.0)$ was added to the digestion. Samples were centrifuged for $10 \mathrm{~min}$ at $12,000 \times \mathrm{g}$, and supernatants were transferred to a fresh tube.

Body composition and food intake. At weaning (3 weeks old), mice were placed on either a diet of standard chow CE-2 (CHD; calories provided by $24.9 \%$ protein, $4.6 \%$ fat, and $70.5 \%$ carbohydrate; CLEA Japan) or a custom high-fat diet (HFD; $58 \mathrm{Y} 1$; calories provided by $18.3 \%$ protein, $60.9 \%$ fat, and $20.1 \%$ carbohydrate; Test Diet). Body weight (BW) was monitored until the age of 16 weeks, when the nose-rump length was measured.

Energy expenditure measurements. In another cohort of mice, food intake and feed efficiency, which was calculated as grams of BW gained per grams of food consumed over a $3 \mathrm{~d}$ period (Sutherland et al., 1974), were evaluated at the age of 8 weeks. Mice at the age of 16 weeks were acclimated to the test cage for $24 \mathrm{~h}$, and energy expenditure was measured at 5 min intervals for $24 \mathrm{~h}$ on the second day (Model Supermex; Muromachi Kikai). Oxygen consumption $\left(V_{\mathrm{O}_{2}}\right)$ and carbon dioxide production $\left(V_{\mathrm{CO}_{2}}\right)$ were measured using electrochemical and spectrophotometric sensors. Resting is defined as $<5 \%$ average max activity counts. In this condition, we calculated the resting $V_{\mathrm{O}_{2}}$. Respiratory quotient (RQ) was calculated as the ratio of $V_{\mathrm{CO}_{2}}$ to $V_{\mathrm{O}_{2}}$. Locomotor activity was measured simultaneously by infrared beam interruption (Model MK-5000RQ/02; Muromachi Kikai) and reported as average counts per hour. Rectal temperature was also measured at the age of 16 weeks with a thermistor (KN-91; Natsume Seisakusho).

Serum levels of insulin and leptin. Blood was collected by tail bleeding from mice at the age of 8 and 16 weeks in the beginning of the light cycle between 09:00 and 10:00 A.M. when mice were in the fed state. Serum was separated by centrifugation at $6000 \times \mathrm{g}$. Serum levels of insulin and leptin were measured by ELISAs (Morinaga Institute of Biological Science, Kanagawa, Japan).

Serum levels of corticosterone in basal and stressed conditions. Male mice at the age of 16 weeks on the CHD were individually restrained for $30 \mathrm{~min}$ in ventilated $50 \mathrm{ml}$ polypropylene tubes. Blood was collected by tail bleeding from mice in basal or stressed conditions, and serum corticosterone levels were measured by ELISA (AssayPro).

Insulin tolerance test and glucose tolerance test. The insulin tolerance test (ITT) and glucose tolerance test (GTT) were performed in male mice at the age of 8 weeks on a HFD as described previously (Banno et al., 2010). Blood glucose was assayed in tail blood using a glucometer (Medisafe mini; Terumo). Measurements were taken at the onset of the light cycle between 09:00 and 10:00 A.M. The insulin dose used for intraperitoneal injections was $1.0 \mathrm{mU} / \mathrm{g} \mathrm{BW}$. Glucose dose used for intraperitoneal injections was $2 \mathrm{mg} / \mathrm{g}$ BW.

In situ hybridization. Mice were killed at the age of 16 weeks in the light cycle between 09:00 and 10:00 A.M., when they were in the fed state, and the brains were rapidly dissected and frozen. In situ hybridization was performed as described previously (Hayashi et al., 2009). The RNA probes were generated from the plasmids of POMC (Sato et al., 2007). Some hybridized sections were dipped in nuclear Kodak NTB2 emulsion (Kodak) and exposed for $2 \mathrm{~d}$ for POMC mRNA to be visualized. To assist cellular localization of the hybridized signals, the emulsion-dipped sections hybridized with POMC mRNA probes were stained with cresyl violet. Any neuronal cross sections with grains of more than threefold the background density were considered labeled.

Immunohistochemistry. Immunohistochemistry was performed in mice at the age of 16 weeks as described previously (Suzuki et al., 2010). The antibodies of GAD67 and vGLUT2 were purchased from Millipore, and those of Synapsin 1, EGFP, and POMC precursor from Synaptic System, MBL, and Phoenix Pharmaceuticals, respectively. After washing, the sections were incubated for $1 \mathrm{~h}$ at room temperature with the secondary antibodies (Alexa Fluor; Life Technologies). All fluorescently stained sections were examined with a fluorescence microscope (BZ-8000; Keyence).

Cell counting. The best-matched slice at $-1.4 \mathrm{~mm}$ caudal from the bregma, according to the brain atlas (Paxinos and Franklin, 2000), was chosen in each mouse for the analysis. Data are presented as the average number of cells per section.

Determination of $m R N A$ levels by real-time PCR. Mice were killed in the light cycle between 09:00 and 10:00 A.M., and the whole hypothalamus was rapidly dissected and frozen in liquid nitrogen. Total RNA was extracted from the hypothalamus using TRIzol (Life Technologies) and the RNeasy kit (QIAGEN). cDNA was synthesized from $1 \mu \mathrm{g}$ total RNA using the High-Capacity cDNA Reverse Transcription Kit (Applied Biosystems). The relative mRNA levels of POMC, NPY, AgRP, IL-6, TNFa, $G f a p$, and $C D 68$ in the hypothalamus were assessed by quantitative realtime PCR (qRT-PCR) using GAPDH as internal control. The qRT-PCR reactions were performed using Brilliant III SYBR Green QPCR Master Mix (Agilent Technologies), and samples were run using the Stratagene $\mathrm{Mx} 3000 \mathrm{p}$. The sequences of primers were as follows: POMC forward, 5'-GAGGCCACTGAACATCTTTGTC; reverse, 5' -GCAGAGGCAAACAAGATTGG; AgRP forward, 5'-CAGAAGCTTTGGCGGAGGT; reverse, 5'-AGGACTCGTGCAGCCTTACAC; NPY forward, 5'-TCAGACCTCTTAATGAAGGAAAGCA; reverse, 5'-GAGAACAAGTTTCA TTTCCCATCA; IL-6 forward, 5'-GTGGCTAAGGACCAAGACCA; reverse, 5'-GGTTTGCCGAGTAGA CCTCA; TNF $\alpha$ forward, 5'CATCTTCTCAAAACTCGAGTGACAA; reverse, 5' -TGGGAGTAGATAAGGTACAGCCC; Gfap forward, 5'-AACGACTATCGCCGCCAACTG; reverse, 5'-CTCTTCCTGTTCGCGCATTTG; Cd68 forward, 5'-CTTCCCACAAGCAGCACAG; reverse, 5' -AATGATGAGAGGCAGCAAGAGA; 
A

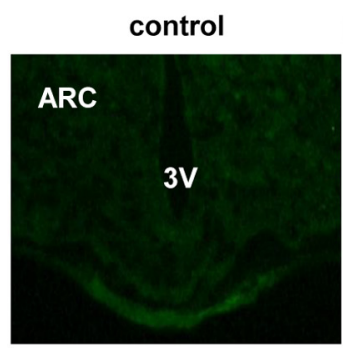

POMC-GABA $_{\mathrm{B} 1} \mathbf{R}^{\star} ; \mathrm{Z} / \mathrm{EG}$

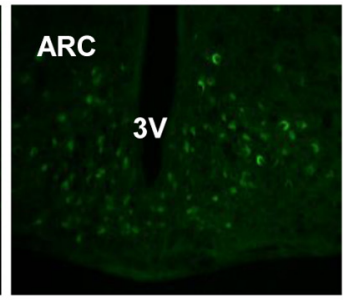

B

WT

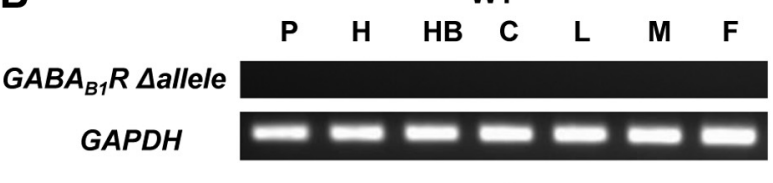

KO

$\mathrm{GABA}_{B 1} R \Delta$ allele

$\begin{array}{lllllll}P & H & H B & C & L & M & F\end{array}$

GAPDH

C
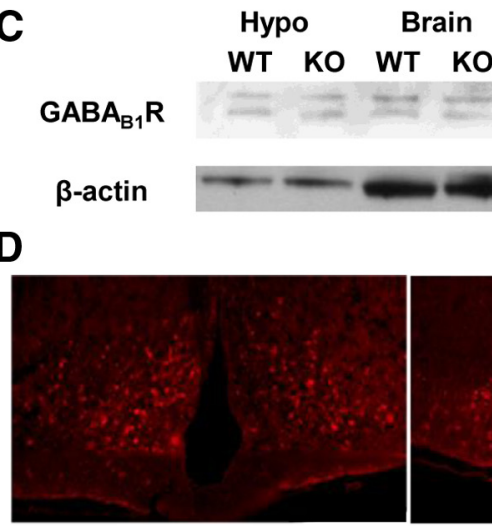

WT

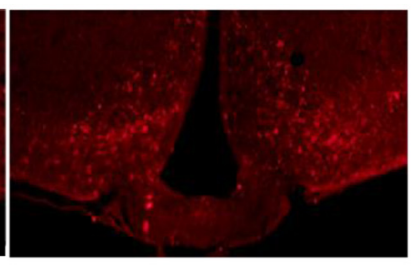

KO

Figure 1. Generation of POMC-specific $G A B A_{B} R$-deficient mice. $A$, Deletion efficiency of POMC-Cre as assessed by immunohistochemistry for EGFP. GABA $A_{B 1} R^{+/+} ; Z / E G$ control hypothalamus (left) compared with POMC-GABA $B_{B} R^{-/[\text {minus] }} ;$ Z/EG hypothalamus (right). ARC, Arcuate nucleus; $3 \mathrm{~V}$, third ventricle. $B$, Detection of deletion of $G A B A_{B 1} R$ alleles $(\triangle)$ in $P O M C-G A B A_{B 1} R^{-/-}$(KO) mice compared with $G A B A_{B 1} R^{+/+}$(WT) mice. DNA was extracted from different tissues, and deletion of the floxed allele was detected by PCR.P, Pituitary; $H$, hypothalamus; $H B$, hindbrain; $C$, cerebral cortex; $\mathrm{L}$, liver; $\mathrm{M}$, skeletal muscle; $\mathrm{F}$, fat. Recombination was detected only in pituitary, hypothalamus, and hindbrain of $K 0$ mice. A PCR reaction with GAPDH was used as an internal control. C, GABA ${ }_{B} R$ protein levels in WT mice compared with $\mathrm{KO}$ mice as determined by immunoblotting. $\beta$-actin protein levels are shown as a loading control. Hypo, Hypothalamus; brain, cerebral cortex. D, POMC cells detected with immunohistochemistry in hypothalamus in WT mice and K0 mice at the age of 16 weeks on the CHD.

GAPDH forward, 5' -AACGACCCCTTCATTGAC; reverse, 5' -TCCACGAC ATACTCAGCAC. Relative mRNA expression was calculated using the comparative Ct method as described previously (Banno et al., 2010).

Determination of protein levels by Western blot. Tissues dissected were frozen immediately in liquid nitrogen. Whole-cell lysates were prepared in a buffer containing $10 \mathrm{~mm}$ Tris, $\mathrm{pH}$ 7.4, $50 \mathrm{~mm} \mathrm{NaF}, 150 \mathrm{~mm} \mathrm{NaCl}$, $0.1 \%$ SDS, $2 \mathrm{~mm} \mathrm{Na}_{3} \mathrm{VO}_{4}, 5 \mathrm{~mm}$ EDTA, and 1\% Triton X-100 (SigmaAldrich) containing fresh protease inhibitors (Rosch), and Western blot was performed as described previously (Ito et al., 2012). Membranes are incubated with $\mathrm{GABA}_{\mathrm{B}} \mathrm{R}$ antibody (Haller et al., 2004). The levels were normalized to $\beta$ actin (Abcam). Blots were quantified using NIH ImageJ software.

Statistical analysis. Statistical significance of the differences between groups was analyzed by unpaired $t$ test, one-way ANOVA, or two-way ANOVA with repeated measures followed by Bonferroni's test. Results
A

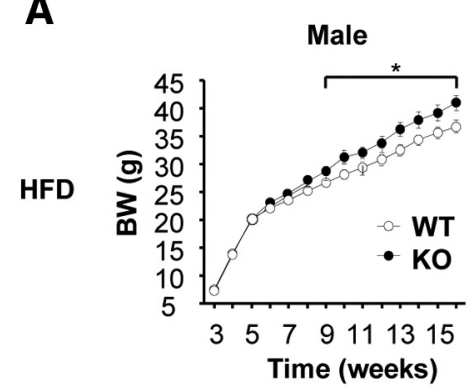

B

C

Male
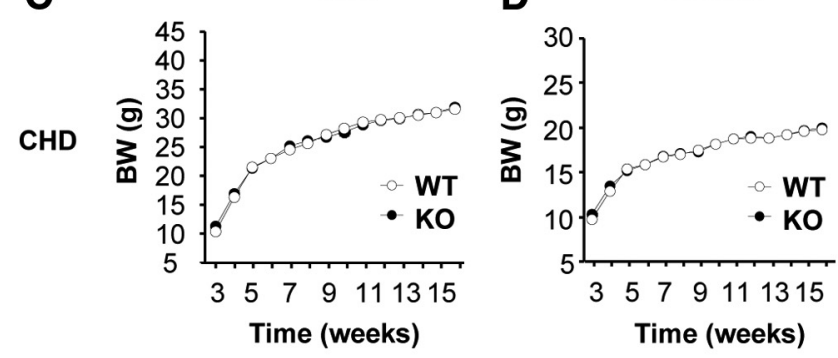

$\mathbf{E}$

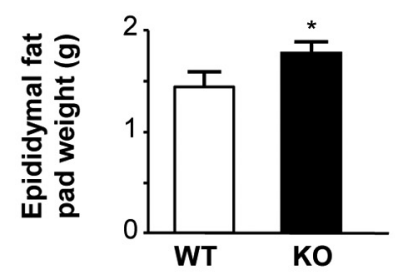

G

$\mathbf{F}$

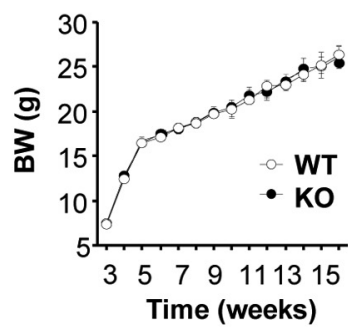

D

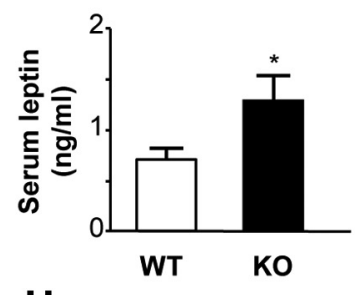

H
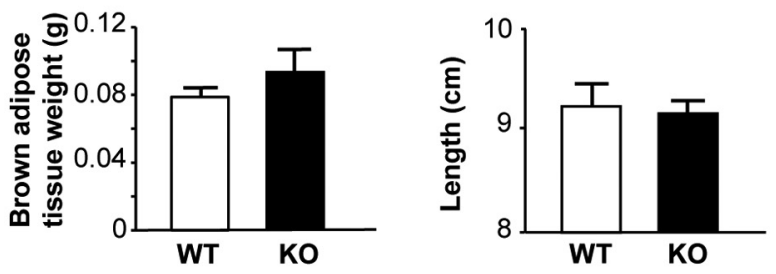

Figure 2. Body weight and composition. $A, B, B W$ of male $(A)$ and female $(B)$ POMC $G A B A_{B 1} R^{-/-}$(KO) mice and $G A B A_{B} R^{+/+}$(WT) mice on a HFD. C, D, BW of male ( $($) and female (D) KO and WT mice on the CHD. $\boldsymbol{E}-\boldsymbol{H}$, Epididymal fat pad weight $(\boldsymbol{E})$, serum leptin levels $(\boldsymbol{F})$, brown adipose tissue weight $(\boldsymbol{G})$, and nose-rump length $(\boldsymbol{H})$ of male $K 0$ and WT mice at the age of 16 weeks on a HFD. All values are mean \pm SE. $n=8$ per genotype. ${ }^{*} p<0.05$ versus WT mice.

are expressed as means \pm SE, and differences were considered significant at $p<0.05$.

\section{Results}

Generation of POMC-specific GABA $A_{B}$-deficient mice

To generate $\mathrm{POMC}$-specific $\mathrm{GABA}_{\mathrm{B}} \mathrm{R}$-deficient mice, $G A B A_{B 1} R^{\text {lox511/lox511 }}$ mice were crossed to POMC-Cre mice to generate $G A B A_{B 1} R^{+/ l o x 511}$ POMC-Cre and $G A B A_{B 1} R^{+/ l o x 511}$ mice. Subsequently, we crossed these mice to $G A B A_{B 1} R^{\text {lox } 511 / \text { lox } 511}$ or $G A B A_{B 1} R^{+ \text {llox511 }}$ mice to yield $G A B A_{B 1} R^{\text {lox511/lox511 }}$ POMC-Cre mice (hereafter termed POMC-GABA ${ }_{B 1} R^{-/-}$or $\mathrm{KO}$ mice), $G A B A_{B 1} R^{+/ l o x 511}$ POMC-Cre mice (hereafter termed POMC$G A B A_{B 1} R^{+/-}$or heterozygous mice), and $G A B A_{B 1} R^{\text {lox511/lox511 }}$ littermate controls (hereafter termed $G A B A_{B 1} R^{+/+}$or WT mice). To visualize POMC cell-specific Cre-mediated recombination, we crossed $G A B A_{B 1} R^{-/-} P O M C$-Cre mice to $Z / E G$ reporter mice, which express EGFP only after Cre-mediated recombination. 


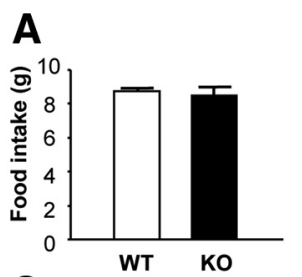

B
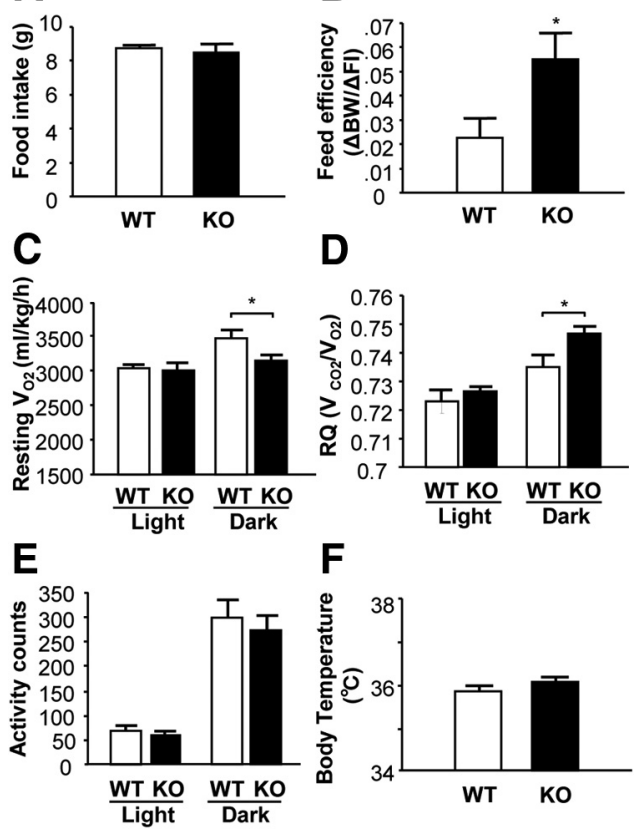

Figure 3. Analysis of energy metabolism. $\boldsymbol{A}$, Cumulative food intake for $3 \mathrm{~d}$. $\boldsymbol{B}$, POMC$G A B A_{B 1} R^{-/-}$(KO) mice have increased feed efficiency compared with $G A B A_{B 1} R^{+/+}$(WT) mice. $C, K 0$ mice have decreased energy expenditure as indicated by decreased resting $V_{0_{2}}$ during the dark cycle compared with WT mice. $\boldsymbol{D}, \mathrm{KO}$ mice have increased RQ values during the dark cycle compared with WT mice. $\boldsymbol{E}, \boldsymbol{F}$, Locomotor activity $(\boldsymbol{E})$ and body temperature $(\boldsymbol{F})$ were not different between genotypes. Data were collected from male mice on a HFD at the age of 8 weeks $(\boldsymbol{A}, \boldsymbol{B})$ and 16 weeks $(\boldsymbol{C}-\boldsymbol{F})$. All values are mean \pm SE. $n=7$ per genotype. ${ }^{*} p<0.05$ versus WT mice.
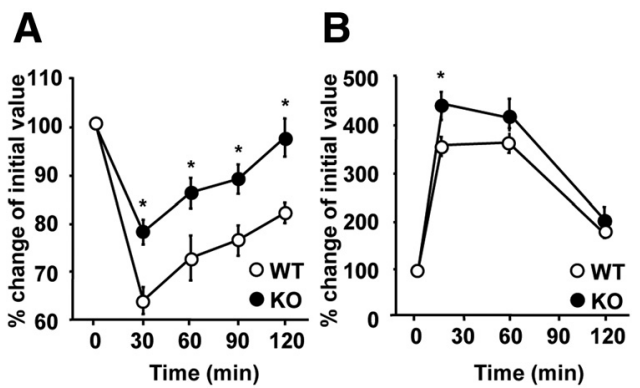

Figure 4. ITT and GTT. Insulin sensitivity and glucose homeostasis are impaired in POMC-

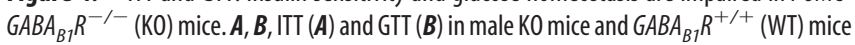
at the age of 8 weeks on a HFD. All values are mean \pm SE. $n=7$ per genotype. ${ }^{*} p<0.05$ versus WT mice.

$G A B A_{B 1} R^{-/-}$; POMC-Cre; Z/EG mice expressed EGFP in the arcuate nucleus in a pattern consistent with POMC neuron localization, whereas control $G A B A_{B 1} R^{-/-} ; Z / E G$ mice did not express EGFP (Fig. 1A). Consistent with areas of endogenous POMC expression, deletion of the $G A B A_{B 1} R$ allele in $\mathrm{KO}$ mice was only detected in DNA extracts from the pituitary, hypothalamus, and hindbrain (including the nucleus of the solitary tract), whereas the recombined alleles were not detected in WT mice (Fig. 1B). Western blot analyses showed no difference in $\mathrm{GABA}_{\mathrm{B}} \mathrm{R}$ protein levels in lysates obtained from whole hypothalamus or brain (Fig. 1C). There were no differences in the number of POMC neurons in the arcuate nucleus between WT and KO mice on the CHD (WT, $39 \pm 5$; KO mice, $40 \pm 3$ ) at the age of 16 weeks. Representative photographs showing POMC immunoreactivities in the arcuate nucleus are shown in Figure $1 D$.
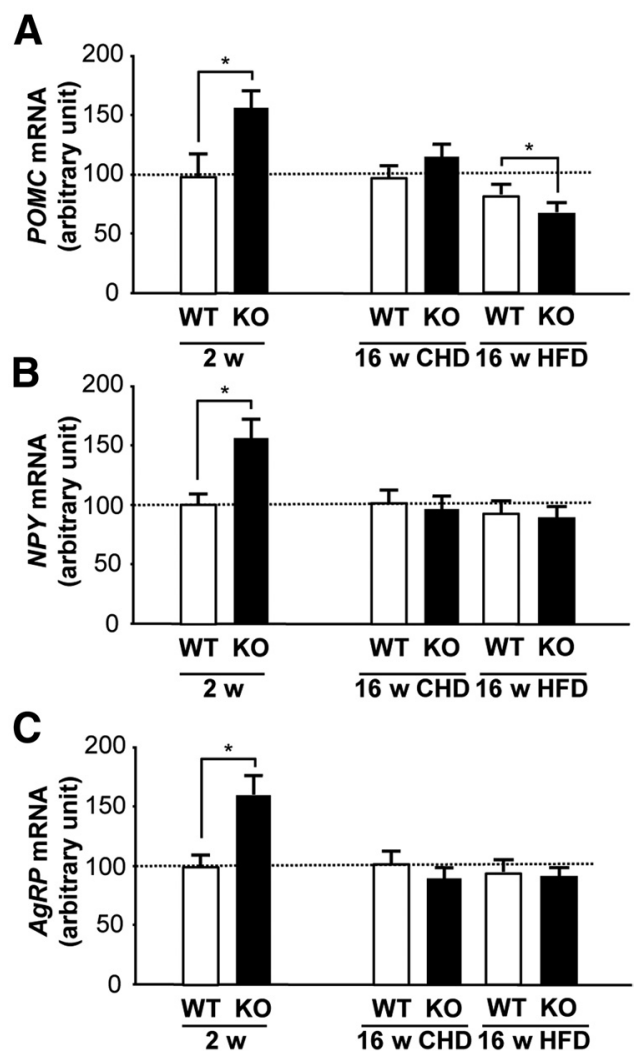

Figure 5. $P O M C, N P Y$, and $A g R P$ mRNA expression in hypothalamus analyzed by RT-PCR. $\boldsymbol{A}-\boldsymbol{C}$, Expression of POMC mRNA (A), NPY mRNA (B), and AgRP mRNA (C) in GABA $B_{B 1} R^{+/+}$(WT) and POMC-GABA $B_{B 1} R^{-/-}(\mathrm{KO})$ mice at ages 2 and 16 weeks on the CHD or HFD. All values are mean \pm SE. $n=6-8$ per genotype. ${ }^{*} p<0.05$ versus WT mice.
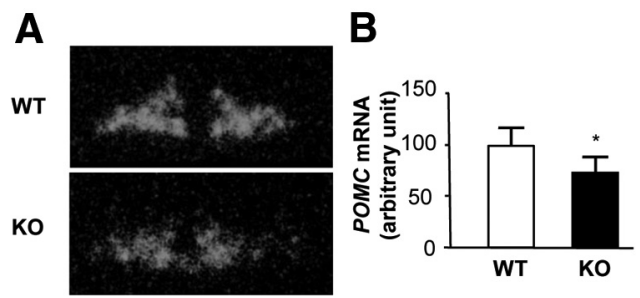

Figure 6. $\quad P O M C$ mRNA expression analyzed by in situ hybridization. $\boldsymbol{A}$, Representative photographs showing POMC mRNA expression in the arcuate nucleus of male $G A B A_{B 1} R^{+/+}$(WT) and POMC-GABA ${ }_{B 1} R^{-1-}$ (KO) mice at the age of 16 weeks on the HFD. $B, P O M C$ mRNA expression was significantly decreased in KO mice compared to WT mice. All values are mean \pm SE. $n=8$ per genotype. ${ }^{*} p<0.05$ versus WT mice.

Changes in BW, adipose tissue weight, and serum leptin levels Analyses with two-way ANOVA with repeated measures showed that the $\mathrm{BW}$ of male $\mathrm{KO}$ mice was significantly higher than that of WT mice on a HFD at 9-16 weeks of age (Fig. $2 A$ ), while the BW of heterozygous mice on a HFD was between that of WT and $\mathrm{KO}$ mice (data not shown). In contrast, female WT and KO mice showed no significant differences in BW on a HFD (Fig. 2B). On the $\mathrm{CHD}$, male or female mice showed no significant differences in BW between genotypes (Fig. 2C,D). Analyses with one-way ANOVA showed that adiposity was increased in male $\mathrm{KO}$ mice on the HFD, as evidenced by increased epididymal fat pad weight (Fig. 2E), while that of heterozygous mice on the HFD was between WT and KO mice (data not shown). Serum leptin levels were significantly higher in male KO mice compared with WT mice at the age of 16 weeks on the HFD (Fig. $2 F$ ), and the levels in 
A
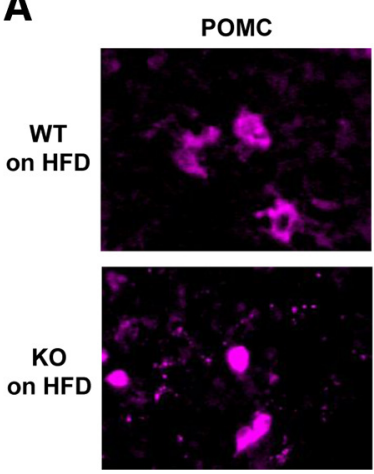

C
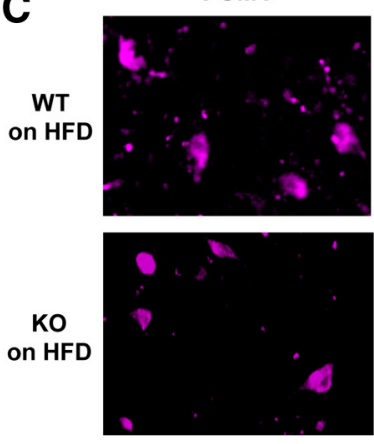

E

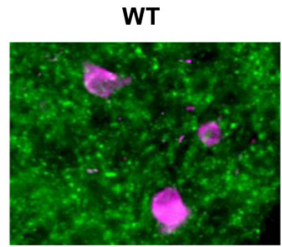

GAD67
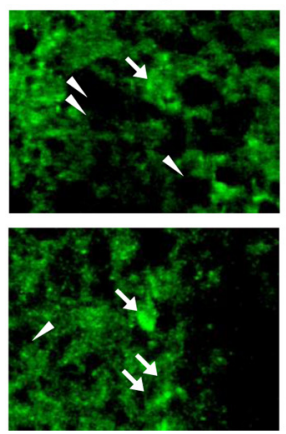

vGlut2
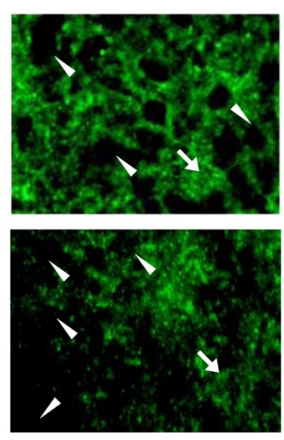

Ko

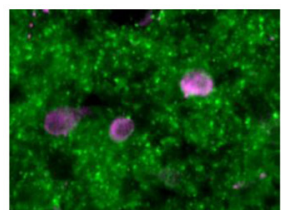

B
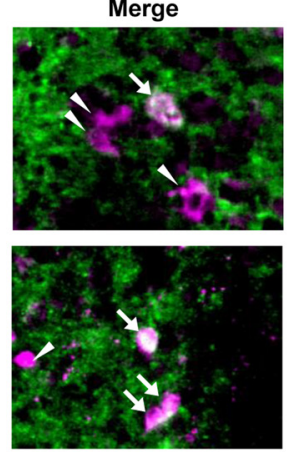

Merge

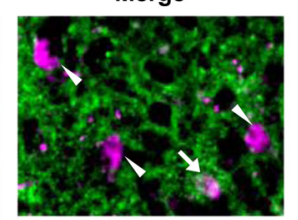

D

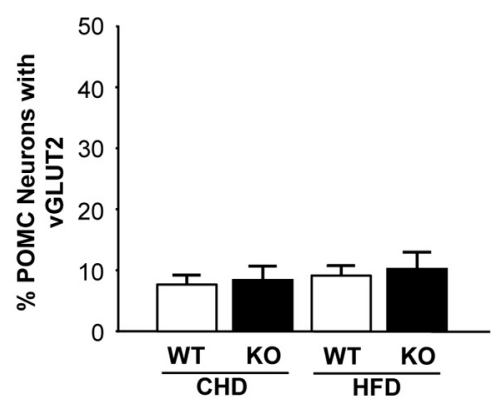

Figure 7. Changes in GABAergic and glutamatergic POMC neurons. $A$, Representative photographs showing the staining of POMC (magenta) and GAD67 (green) in the arcuate nucleus in male WT and KO mice at the age of 16 weeks on the HFD. B, GABAergic POMC neurons were significantly decreased in WT mice but not in KO mice on the HFD. C, Representative photographs showing the staining of POMC (magenta) and VGLUT2 (green) in the arcuate nucleus in male WT and KO mice at the age of 16 weeks on the HFD. $D$, There were no differences in numbers of glutamatergic POMC neurons between WT mice and KO mice on the HFD or CHD. E, Expression of Synapsin 1 in the region of POMC neurons. POMC neurons (magenta) and Synapsin 1 expression (green) in the arcuate nucleus in WT and KO mice at the age of 16 weeks on the HFD are shown. POMC neurons colocalized with GAD 67 or vGLUT2 were shown by arrows, whereas those not thus colocalized were shown by arrowheads. All values are mean \pm SE. $n=6$ per genotype. ${ }^{*} p<0.05$ versus WT mice.

heterozygous mice were between WT and KO mice (data not shown). No significant differences were found in brown adipose tissue (BAT) weight or body length between male WT and KO mice on the HFD (Fig. 2G,H). There were no significant differences in adiposity, serum leptin levels, BAT weight, and body length between female WT and KO mice on the CHD or HFD (data not shown).

\section{Food intake and energy expenditure}

Food intake was similar between male WT and KO mice on a HFD (Fig. $3 A$ ), but feed efficiency ( $\Delta B W / \Delta$ food intake) was significantly higher in the KO mice compared with WT mice (Fig. $3 B$ ). Resting $V_{\mathrm{O}_{2}}$ was decreased and $\mathrm{RQ}$ was increased in male $\mathrm{KO}$ mice compared with WT mice during the dark cycle (Fig. 3C,D). No differences between genotypes were noted in locomotor activity or body temperature (Fig. $3 E, F$ ).

Insulin sensitivity and glucose tolerance

No differences between genotypes were noted in fasted serum glucose, serum insulin levels, or homeostasis model assessment ratio in male mice at the age of 8 weeks on a HFD (data not shown). However, male KO mice were less insulin sensitive, as measured by ITT, and showed hyperglycemia during the GTT

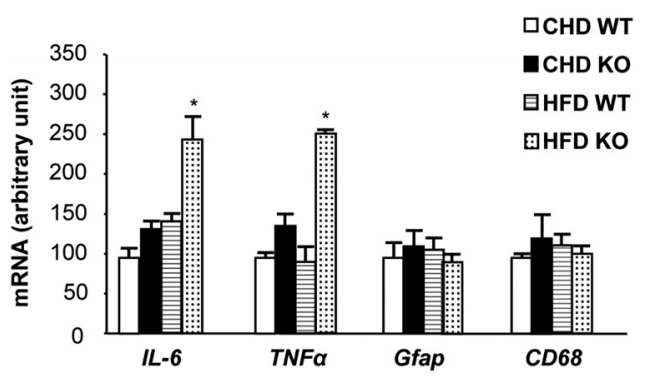

Figure 8. Hypothalamic inflammatory signaling. Hypothalamic expression of inflammation signals (IL-6, TNF $\alpha$ ) were increased in POMC-GABA $A_{B 1} R^{-/-}$(KO) mice on the HFD at the age of 16 weeks compared to $\mathrm{KO}$ mice on the CHD, or $G A B A_{B 1} R^{+/+}$(WT) mice on the CHD or HFD. Expression levels of microglia-specific (Gfap) and astrocyte-specific (CD68) markers were not different between groups. All values are mean \pm SE. $n=5-8$ per genotype. ${ }^{*} p<0.05$ versus KO mice on the CHD, WT mice on the CHD, or WT mice on the HFD.

compared to WT mice at the age of 8 weeks (Fig. $4 A, B$ ), when there were no significant differences in BW between genotypes.

Serum levels of corticosterone in basal and stressed conditions Serum levels of corticosterone in stressed conditions were significantly increased compared to those in basal conditions in both 
male WT and KO mice, and there were no significant differences between genotypes in the levels in basal (WT, $144.3 \pm 18.3 \mathrm{pg} / \mathrm{ml}$; $\mathrm{KO}, 155.0 \pm 21.3 \mathrm{pg} / \mathrm{ml}$ ) or stressed conditions (WT, $271.8 \pm$ $39.4 \mathrm{pg} / \mathrm{ml} ; \mathrm{KO}, 344.0 \pm 57.6 \mathrm{pg} / \mathrm{ml}$ ).

POMC, NPY, and AgRP mRNA expression

Male KO mice had increased hypothalamic POMC, NPY, and AgRP mRNA expression compared to the WT mice at the age of 2 weeks (Fig. 5), whereas there were no differences in the expression levels between 2-week-old male WT and POMC-Cre mice (data not shown). While no differences in POMC, NPY, and $A g R P$ mRNA expression were noted between 16-week-old male $\mathrm{KO}$ and WT mice on the CHD (Fig. 5), male KO mice on a HFD had significantly decreased hypothalamic $P O M C$ mRNA expression (Fig. 5A); no significant changes were observed in NPY and $A g R P$ mRNA expression (Fig. $5 B, C$ ). In situ analysis hybridization also confirmed that POMC mRNA expression in the arcuate nucleus was significantly decreased in male KO mice on a HFD compared to WT mice (Fig. 6A,B). No differences were found in the number of cells expressing POMC mRNA in the arcuate nucleus between male WT $(38 \pm 2)$ and $\mathrm{KO}$ mice $(36 \pm 2)$ on a HFD.

GABAergic and glutamatergic POMC neurons

GABAergic POMC neurons in WT and $\mathrm{KO}$ mice on the CHD comprised $\sim 30 \%$ of the total number of POMC neurons, and they were decreased in number in WT mice on the HFD, but not in $\mathrm{KO}$ mice (Fig. $7 A, B$ ). On the other hand, the number of glutamatergic POMC neurons was low (less than10\%), and there were no changes between genotypes on the CHD or HFD (Fig. $7 C, D)$. No differences were found in the number of POMC neurons in the arcuate nucleus between male WT (40 \pm 3$)$ and $\mathrm{KO}$ mice ( $36 \pm 3$ ) on the HFD. There were no apparent differences in the staining of Synapsin 1, a marker of total synapses (Cesca et al., 2010), in the region of POMC neurons between WT and KO mice on the CHD or HFD (Fig. 7E).

\section{Hypothalamic inflammatory signaling}

$I L-6$ and $T N F \alpha$ mRNA expression were significantly increased in male KO mice on the HFD compared with that in KO mice on the CHD or that in WT mice on the CHD or HFD (Fig. 8). Expression levels of Gfap and CD68, makers of astrocyte and microglia activation, respectively (Thaler et al., 2012), were not significantly different between groups (Fig. 8).

\section{Discussion}

In the present study, we generated POMC-specific $G A B A_{B 1} R \mathrm{KO}$ mice. We demonstrated that the male KO mice on a HFD exhibited mild increases in BW accompanied by decreased energy expenditure. The male KO mice also showed insulin resistance at the age of 8 weeks, when there were no significant differences in BW between genotypes. Furthermore, the POMC mRNA expression in the arcuate nucleus decreased and hypothalamic inflammation increased in the male KO mice at the age of 16 weeks. On the other hand, it is reported that there is no difference in BW between POMC-Cre and WT mice on a HFD (Banno et al., 2010). We also demonstrated that expression levels of $P O M C, N P Y$, and $A g R P$ mRNA are not different among POMC-Cre and WT mice, excluding the possibility that the Cre protein itself generated the phenotypes. Together, we suggest that signaling through $\mathrm{GABA}_{\mathrm{B}} \mathrm{Rs}$ in POMC neurons is essential in the regulation of both energy balance and glucose homeostasis.

While $\mathrm{GABA}_{\mathrm{A}} \mathrm{Rs}$ mediate fast GABA responses by triggering chloride channel opening, $\mathrm{GABA}_{\mathrm{B}} \mathrm{Rs}$ mediate slower GABA re-
A

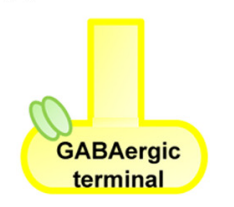

GABA

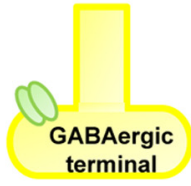

Glutamate

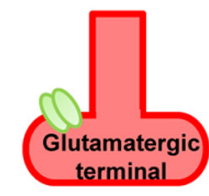

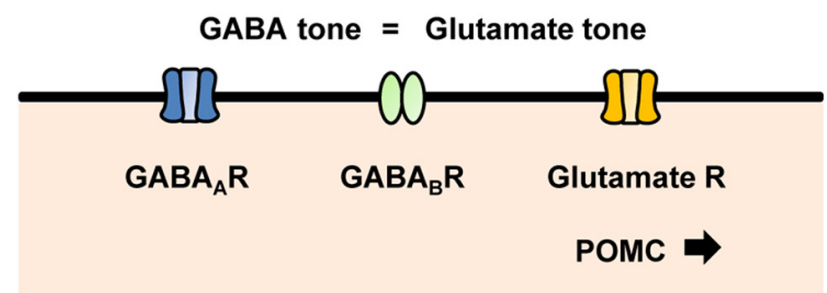

B
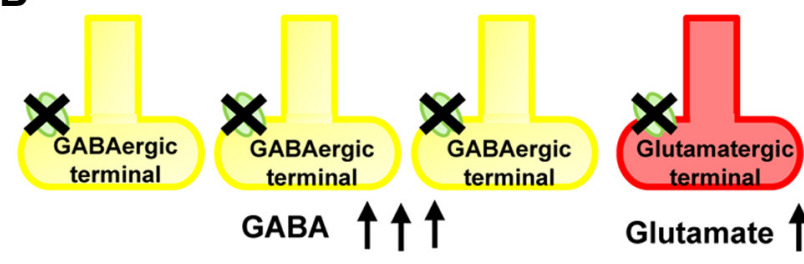

GABA tone > Glutamate tone

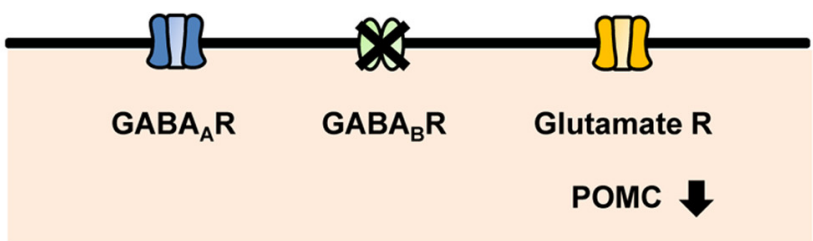

Figure 9. Possible mechanisms by which POMC expression was affected in POMC-specific $G A B A_{B} R K 0$ mice. $A, G A B A_{B} R$ s are located presynaptically and postsynaptically in POMC neurons, which release GABA and glutamate. $B$, GABAergic POMC neurons are increased in $\mathrm{GABA}_{B} R \mathrm{KO}$ mice compared to WT mice on a HFD. Deletion of $G_{A B A} R$ ss in GABAergic terminals leads to increases in $G A B A$ release, whereas that in glutamatergic terminals results in increases in glutamate. Increased GABA release could decrease POMC expression through action on $G_{A B} A_{A} R s$.

sponses by activating G-proteins that regulate second messenger systems as well as effector $\mathrm{K}^{+}$and $\mathrm{Ca}^{2+}$ channels (Gassmann and Bettler, 2012). $G_{A B A}$ Rs are located both presynaptically and postsynaptically. Presynaptic $\mathrm{GABA}_{\mathrm{B}}$ Rs are present at GABAergic (autoreceptors) and glutamatergic terminals (heteroreceptors; Gassmann and Bettler, 2012). While most POMC neurons are reported to be GABAergic, it is also shown that some POMC neurons release glutamate, and that the released GABA and glutamate from POMC neurons regulate the activity of the neurons themselves as well as the activity of interconnected POMC neurons (Dicken et al., 2012). Thus, the effects of deletion of $\mathrm{GABA}_{\mathrm{B}} \mathrm{Rs}$ in POMC neurons would be determined by the balance between the effects of deleting postsynaptic and presynaptic $\mathrm{GABA}_{\mathrm{B}}$ Rs. Consistent with previous studies (Jarvie and Hentges, 2012 ), our data show that $\sim 30 \%$ of POMC neurons are GABAergic, while glutamatergic POMC neurons comprise $<10 \%$. It is also demonstrated that GABAergic POMC neurons were decreased in WT mice on a HFD, but not in KO mice. While the mechanisms by which GABAergic POMC neurons were decreased in WT mice on a HFD remain to be clarified, it was reported that the density of excitatory and inhibitory synapses onto POMC neurons was changed in leptin-deficient $(o b / o b)$ mice (Pinto et al., 2004). Thus, the synaptic alterations may be 
induced by changes in energy balance, and $\mathrm{GABA}_{\mathrm{B}} \mathrm{Rs}$ in POMC neurons appear to be prerequisite for the regulation of GABAergic POMC neurons on a HFD. Although our data did not reveal significant changes in glutamatergic POMC neurons or Synapsin 1 staining, a more sensitive approach may also reveal changes in the number of glutamatergic POMC neurons or in the total number of synaptic inputs onto the POMC neurons on a HFD.

The deletion of $\mathrm{GABA}_{\mathrm{B}}$ autoreceptors would increase GABA release, whereas that of the heteroreceptors would lead to increases in glutamate release (Fig. 9). In the case of POMC neurons, the effects of deletion of $\mathrm{GABA}_{\mathrm{B}}$ autoreceptors would be more dominant than those of the heteroreceptors given that there are more GABAergic than glutamatergic POMC neurons, and the increased release of GABA would inhibit POMC neuronal activity through $\mathrm{GABA}_{\mathrm{A}}$ Rs. This is a possible mechanism by which POMC expression is decreased in 16-week-old $\mathrm{KO}$ mice on a HFD, in which the number of GABAergic POMC neurons was increased compared to age-matched WT mice on a HFD (Fig. 9). To prove this hypothesis, it would be necessary in future studies to address whether central injection of $\mathrm{GAB}_{\mathrm{A}} \mathrm{A}$ antagonists can reverse phenotype such as obesity or insulin resistance in $\mathrm{KO}$ mice on a HFD. In addition to the autoregulatory mechanism, the activities of POMC neurons are regulated by other neurons including NPY neurons. Thus, further investigation is warranted to clarify the mechanisms by which POMC expression is changed in POMC-specific $G A B A_{B 1} R$ KO mice.

It is also important to note that effects of changes in the activity of anorexigenic POMC neurons on energy balance could be compensated by orexigenic neurons in the KO mice. In this context, the findings that there were no differences in BW between genotypes in 2-week-old $\mathrm{KO}$ mice, in which POMC expression was increased, could be explained through an upregulation of anorexigenic $P O M C$ expression that was compensated by increased orexigenic $N P Y$ and $A g R P$ expression. On the other hand, decreased POMC expression was not accompanied by significant changes in NPY and AgRP expression in the obese 16-week-old $\mathrm{KO}$ mice on a HFD. As the expression of anorexigenic POMC is expected to increase when $\mathrm{BW}$ is increased, the decreased activity of POMC neurons is likely to contribute, at least in part, to late onset of obesity in POMC-specific $G A B A_{B 1} R \mathrm{KO}$ mice. Our data also show that serum leptin levels were increased in POMCspecific $G A B A_{B 1} R$ KO mice compared to WT mice on a HFD. Leptin decreases food intake and BW by activating POMC neurons (Schwartz et al., 2000), and obesity is often associated with leptin resistance (Ahima and Flier, 2000). Therefore, it is possible that POMC-specific deletion of $G A B A_{B 1} R$ increased leptin resistance in the POMC neurons on a HFD, which would possibly cause the phenotypes in the $\mathrm{KO}$ mice.

Interestingly, while BW increases in POMC-specific $G A B A_{B 1} R$ KO mice are relatively mild, expression of TNF $\alpha$ and IL6, two proinflammatory markers in the hypothalamus, was increased more than twofold in the KO mice compared to WT mice on a HFD. These results suggest that the deletion of $G_{A B A} R$ in POMC neurons leads to hypothalamic inflammation on a HFD. There is evidence to suggest that hypothalamic inflammation is related to the onset of obesity (Gregor and Hotamisligil, 2011), and previous studies showed that hypothalamic inflammation occurred even in WT mice on a HFD (Zhang et al., 2008; Kirchner et al., 2012; Thaler et al., 2012). Together with the findings in the present study, it is suggested that $\mathrm{GABA}_{\mathrm{B}} \mathrm{Rs}$ in POMC neurons are essential to protect the hypothalamus from inflammation on a HFD. It is also reported that, with a HFD, gliosis in the hypothalamus is increased and that POMC neurons died by au- tophagy (Thaler et al., 2012). In contrast, our data showed there is no increase in the expression of gliosis markers (Gfap or CD68) or neuronal loss of POMC. The discrepancy between studies could be explained by the difference of duration of a HFD [ 3 months in the present study versus 8 months in the previous study by Thaler et al. (2012)].

$\mathrm{GABA}_{\mathrm{B}}$ Rs have been implicated in a wide variety of neurological and psychiatric conditions (Gassmann and Bettler, 2012). Regarding energy balance, it is reported that full $G A B A_{B 1} R$ KO mice are insulin resistant, with males being more affected than females (Bonaventura et al., 2008, 2012). We reported in a previous study (Sato et al., 2007) that baclofen, which crosses bloodbrain barrier (van Bree et al., 1991), reduced BW in diet-induced obese mice as well as $d b / d b$ mice, with POMC mRNA expression in the arcuate nucleus being increased, while the BW in lean mice was unaffected. Our clinical trial also demonstrated that baclofen reduced BW in obese subjects (Arima and Oiso, 2010). The present study further supports the role of $\mathrm{GABA}_{\mathrm{B}} \mathrm{R}$ signaling in energy balance and points to the important role of $G_{A B A} R$ signaling in POMC neurons.

POMC is expressed not only in the arcuate nucleus, but also in the pituitary and hindbrain, and the recombination of the floxed $G A B A_{B 1}$ allele was detected at these sites in the POMC-specific $G A B A_{B I} R \mathrm{KO}$ mice. As for the pituitary, there are no differences in corticosterone levels in basal and stressed conditions between the KO and WT mice, suggesting that the hypothalamic-pituitary-adrenal axis is intact in the $\mathrm{KO}$ mice. However, these data do not necessarily exclude roles of $G_{A B A} R$ Rs expressed in the pituitary in the control of energy balance. Furthermore, there is evidence that POMC neurons in the hindbrain are involved in the energy balance (Ellacott et al., 2006). Thus, further studies are required to clarify the relative contributions of $\mathrm{GABA}_{\mathrm{B}} \mathrm{R}$ ablation in the arcuate nucleus, pituitary and the hindbrain to the control of energy balance or glucose tolerance in male mice.

In conclusion, we demonstrated that regulation of POMC neurons via $G_{A B A} R$ signaling plays an important role in the energy homeostasis, glucose tolerance, and prevention of hypothalamic inflammation on a HFD.

\section{References}

Ahima RS, Flier JS (2000) Leptin. Annu Rev Physiol 62:413-437. CrossRef Medline

Aizawa-Abe M, Ogawa Y, Masuzaki H, Ebihara K, Satoh N, Iwai H, Matsuoka N, Hayashi T, Hosoda K, Inoue G, Yoshimasa Y, Nakao K (2000) Pathophysiological role of leptin in obesity-related hypertension. J Clin Invest 105:1243-1252. CrossRef Medline

Arima H, Oiso Y (2010) Positive effect of baclofen on body weight reduction in obese subjects: a pilot study. Intern Med 49:2043-2047. CrossRef Medline

Balthasar N, Coppari R, McMinn J, Liu SM, Lee CE, Tang V, Kenny CD, McGovern RA, Chua SC Jr, Elmquist JK, Lowell BB (2004) Leptin receptor signaling in POMC neurons is required for normal body weight homeostasis. Neuron 42:983-991. CrossRef Medline

Banno R, Zimmer D, De Jonghe BC, Atienza M, Rak K, Yang W, Bence KK (2010) PTP1B and SHP2 in POMC neurons reciprocally regulate energy balance in mice. J Clin Invest 120:720-734. CrossRef Medline

Bonaventura MM, Catalano PN, Chamson-Reig A, Arany E, Hill D, Bettler B, Saravia F, Libertun C, Lux-Lantos VA (2008) GABAB receptors and glucose homeostasis: evaluation in GABAB receptor knockout mice. Am J Physiol Endocrinol Metab 294:E157-E167. Medline

Bonaventura MM, Rodriguez D, Ferreira ML, Crivello M, Repetto EM, Bettler B, Libertun C, Lux-Lantos VA (2012) Sex differences in insulin resistance in GABAB1 knockout mice. Life Sci 95:175-182. Medline

Cesca F, Baldelli P, Valtorta F, Benfenati F (2010) The synapsins: key actors of synapse function and plasticity. Prog Neurobiol 91:313-348. CrossRef Medline 
Coll AP, Farooqi IS, Challis BG, Yeo GS, O’Rahilly S (2004) Proopiomelanocortin and energy balance: insights from human and murine genetics. J Clin Endocrinol Metab 89:2557-2562. CrossRef Medline

Cowley MA, Smart JL, Rubinstein M, Cerdán MG, Diano S, Horvath TL, Cone RD, Low MJ (2001) Leptin activates anorexigenic POMC neurons through a neural network in the arcuate nucleus. Nature 411:480-484. CrossRef Medline

Dicken MS, Tooker RE, Hentges ST (2012) Regulation of GABA and glutamate release from proopiomelanocortin neuron terminals in intact hypothalamic networks. J Neurosci 32:4042-4048. CrossRef Medline

Ellacott KL, Halatchev IG, Cone RD (2006) Characterization of leptinresponsive neurons in the caudal brainstem. Endocrinology 147:31903195. CrossRef Medline

Enna SJ, McCarson KE (2006) The role of GABA in the mediation and perception of pain. Adv Pharmacol 54:1-27. CrossRef Medline

Fan W, Boston BA, Kesterson RA, Hruby VJ, Cone RD (1997) Role of melanocortinergic neurons in feeding and the agouti obesity syndrome. Nature 385:165-168. CrossRef Medline

Gassmann M, Bettler B (2012) Regulation of neuronal GABA(B) receptor functions by subunit composition. Nat Rev Neurosci 13:380-394. CrossRef Medline

Gregor MF, Hotamisligil GS (2011) Inflammatory mechanisms in obesity. Annu Rev Immunol 29:415-445. CrossRef Medline

Haller C, Casanova E, Müller M, Vacher CM, Vigot R, Doll T, Barbieri S, Gassmann M, Bettler B (2004) Floxed allele for conditional inactivation of the GABAB(1) gene. Genesis 40:125-130. CrossRef Medline

Harrold JA, Widdowson PS, Williams G (2003) $\beta$-MSH: a functional ligand that regulated energy homeostasis via hypothalamic MC4-R? Peptides 24:397-405. CrossRef Medline

Hayashi M, Arima H, Ozaki N, Morishita Y, Hiroi M, Ozaki N, Nagasaki H, Kinoshita N, Ueda M, Shiota A, Oiso Y (2009) Progressive polyuria without vasopressin neuron loss in a mouse model for familial neurohypophysial diabetes insipidus. Am J Physiol Regul Integr Comp Physiol 296:R1641-1649. CrossRef Medline

Honda K, Saneyasu T, Hasegawa S, Kamisoyama H (2012) A comparative study of the central effects of melanocortin peptides on food intake in broiler and layer chicks. Peptides 37:13-17. CrossRef Medline

Huszar D, Lynch CA, Fairchild-Huntress V, Dunmore JH, Fang Q, Berkemeier LR, Gu W, Kesterson RA, Boston BA, Cone RD, Smith FJ, Campfield LA, Burn P, Lee F (1997) Targeted disruption of the melanocortin-4 receptor results in obesity in mice. Cell 88:131-141. CrossRef Medline

Ito Y, Banno R, Hagimoto S, Ozawa Y, Arima H, Oiso Y (2012) TNFalpha increases hypothalamic PTP1B activity via the NFkappaB pathway in rat hypothalamic organotypic cultures. Regul Pept 174:58-64. CrossRef Medline

Jarvie BC, Hentges ST (2012) Expression of GABAergic and glutamatergic phenotypic markers in hypothalamic proopiomelanocortin neurons. J Comp Neurol 520:3863-3876. CrossRef Medline

Jonsson L, Skarphedinsson JO, Skuladottir GV, Atlason PT, Eiriksdottir VH, Franzson L, Schiöth HB (2001) Melanocortin receptor agonist transiently increases oxygen consumption in rats. Neuroreport 12:3703-3708. CrossRef Medline

Kievit P, Howard JK, Badman MK, Balthasar N, Coppari R, Mori H, Lee CE, Elmquist JK, Yoshimura A, Flier JS (2006) Enhanced leptin sensitivity and improved glucose homeostasis in mice lacking suppressor of cytokine signaling-3 in POMC-expressing cells. Cell Metab 4:123-132. CrossRef Medline

Kirchner H, Hofmann SM, Fischer-Rosinský A, Hembree J, Abplanalp W, Ottaway N, Donelan E, Krishna R, Woods SC, Müller TD, Spranger J, Perez-Tilve D, Pfluger PT, Tschöp MH, Habegger KM (2012) Caloric restriction chronically impairs metabolic programming in mice. Diabetes 61:2734-2742. CrossRef Medline
Morton GJ, Cummings DE, Baskin DG, Barsh GS, Schwartz MW (2006) Central nervous system control of food intake and body weight. Nature 443:289-295. CrossRef Medline

Nogueiras R, Wiedmer P, Perez-Tilve D, Veyrat-Durebex C, Keogh JM, Sutton GM, Pfluger PT, Castaneda TR, Neschen S, Hofmann SM, Howles PN, Morgan DA, Benoit SC, Szanto I, Schrott B, Schürmann A, Joost HG, Hammond C, Hui DY, Woods SC, et al. (2007) The central melanocortin system directly controls peripheral lipid metabolism. J Clin Invest 117:3475-3488. CrossRef Medline

Novak A, Guo C, Yang W, Nagy A, Lobe CG (2000) Z/EG, a double reporter mouse line that expresses enhanced green fluorescent protein upon Cremediated excision. Genesis 28:147-155. CrossRef Medline

Obici S, Feng Z, Tan J, Liu L, Karkanias G, Rossetti L (2001) Central melanocortin receptors regulate insulin action. J Clin Invest 108:1079-1085. CrossRef Medline

Paxinos G, Franklin KB (2000) The mouse brain in stereotaxic coordinates. New York: Academic.

Pinto S, Roseberry AG, Liu H, Diano S, Shanabrough M, Cai X, Friedman JM, Horvath TL (2004) Rapid rewiring of arcuate nucleus feeding circuits by leptin. Science 304:110-115. CrossRef Medline

Sato I, Arima H, Ozaki N, Ozaki N, Watanabe M, Goto M, Shimizu H, Hayashi M, Banno R, Nagasaki H, Oiso Y (2007) Peripherally administered baclofen reduced food intake and body weight in $\mathrm{db} / \mathrm{db}$ as well as diet-induced obese mice. FEBS Lett 581:4857-4864. CrossRef Medline

Schuler V, Lüscher C, Blanchet C, Klix N, Sansig G, Klebs K, Schmutz M, Heid J, Gentry C, Urban L, Fox A, Spooren W, Jaton AL, Vigouret J, Pozza M, Kelly PH, Mosbacher J, Froestl W, Käslin E, Korn R, et al. (2001) Epilepsy, hyperalgesia, impaired memory, and loss of pre- and postsynaptic GABA(B) responses in mice lacking $\operatorname{GABA}(\mathrm{B}(1))$. Neuron 31:47-58. CrossRef Medline

Schwartz MW, Woods SC, Porte D Jr, Seeley RJ, Baskin DG (2000) Central nervous system control of food intake. Nature 404:661-671. Medline

Sutherland TM, Biondini PE, Ward GM (1974) Selection for growth rate, feed efficiency and body composition in mice. Genetics 78:525-540. Medline

Suzuki H, Sugimura Y, Iwama S, Suzuki H, Nobuaki O, Nagasaki H, Arima H, Sawada M, Oiso Y (2010) Minocycline prevents osmotic demyelination syndrome by inhibiting the activation of microglia. J Am Soc Nephrol 21:2090-2098. CrossRef Medline

Thaler JP, Yi CX, Schur EA, Guyenet SJ, Hwang BH, Dietrich MO, Zhao X, Sarruf DA, Izgur V, Maravilla KR, Nguyen HT, Fischer JD, Matsen ME, Wisse BE, Morton GJ, Horvath TL, Baskin DG, Tschop MH, Schwartz MW (2012) Obesity is associated with hypothalamic injury in rodents and humans. J Clin Invest 122:153-162. CrossRef

Tong Q, Ye CP, Jones JE, Elmquist JK, Lowell BB (2008) Synaptic release of GABA by AgRP neurons is required for normal regulation of energy balance. Nat Neurosci 11:998-1000. CrossRef Medline

van Bree JB, Heijligers-Feijen CD, de Boer AG, Danhof M, Breimer DD (1991) Stereoselective transport of baclofen across the blood-brain barrier in rats as determined by the unit impulse response methodology. Pharm Res 8:259-262. CrossRef Medline

Xu AW, Ste-Marie L, Kaelin CB, Barsh GS (2007) Inactivation of signal transducer and activator of transcription 3 in proopiomelanocortin (Pomc) neurons causes decreased pomc expression, mild obesity, and defects in compensatory refeeding. Endocrinology 148:72-80. Medline

Yaswen L, Diehl N, Brennan MB, Hochgeschwender U (1999) Obesity in the mouse model of pro-opiomelanocortin deficiency responds to peripheral melanocortin. Nat Med 5:1066-1070. CrossRef Medline

Zhang X, Zhang G, Zhang H, Karin M, Bai H, Cai D (2008) Hypothalamic IKKbeta/NF-kappaB and ER stress link overnutrition to energy imbalance and obesity. Cell 135:61-73. CrossRef Medline 